\title{
Rearing suckling Polish Lowland lambs on creep feed with different protein levels
}

\author{
J.J. Pająk, T. Żebrowska, M. Słowak and Z. Długolęcka \\ The Kielanowski Institute of Animal Physiology and Nutrition, Polish Academy of Sciences \\ 05-110 Jabionna, Poland
}

(Received 21 October 1999 ; accepted 8 May 2000)

\begin{abstract}
Four groups of 44 suckling lambs (30 male and 14 female) were given supplementary feeds: meadow hay and a concentrate with barley containing: 162,135 or $103 \mathrm{~g}$ crude protein in dry matter (groups H, M and L, respectively) or a mixture with oats, containing $138 \mathrm{~g}$ crude protein, group C. Restricting crude protein in the mixture to about $14 \%$ in DM did not have a detrimental effect on the growth of lambs, but when the mixture containing about $10 \%$ protein was given, the body weight gain of male lambs significantly declined. From day 28 of life to weaning at 89-93 days, the body weight gains of ewes did not differ among groups and equaled $120-132 \mathrm{~g}$ per day, while male lambs gained $142^{\mathrm{a}}, 147^{\mathrm{a}}, 126^{\mathrm{al}}$ and $115^{\mathrm{b}} \mathrm{g}(\mathrm{P}<0.05)$ daily in groups $\mathrm{C}, \mathrm{H}, \mathrm{M}$ and $\mathrm{L}$, respectively. The intake of dry matter from creep feed by suckling lambs was markedly lower than given in the IZ standards.
\end{abstract}

KEY WORDS: Polish Lowland lambs, creep feed, protein level, suckling lambs

\section{INTRODUCTION}

Suckling lambs obtain sufficient nutrients and energy from milk to cover maintenance and growth for the first four weeks of life. As the amount of milk produced by the mother decreases, it becomes necessary to add concentrates to the lamb's diet (Snowder and Glimp, 1991); the relatively early introduction of dry feed promotes the devclopment of digestive functions in young lambs (Ørskov, 1983).

There is little data in the literature on the cffects of creep fecding suckling lambs of Polish breeds on their rearing and later performance. According to Potkański et al. (1991a,b) partial replacement of soyabean oilmeal with rapeseed oilmeal or rape seed in the mixture given suckling Polish Merino lambs did not affect their growth rate. The body weight gains of Polish Lowland lambs were, 
however, lower when they were given a mixture containing ground yellow lupin seeds instead of soyabean oilmeal (Pająk et al., 1999). Feed intake and body weight gain were lower when the lambs were fed mixtures with a lower crude protein content than when a high-protein feed was given (12 vs $17 \%$ in DM), but the suckling lambs creep fed with high protcin contents grew more slowly during fattening and showed poorer feed utilisation (Pająk et al., 1994). However differences in final body weight and average daily gain between the groups Gaddi $x$ Merino lambs fed from 7 to 90 day of life isoenergetic creep diets containing 11-21\% CP were not significant (Sawal et al., 1996). Those authors suggest that creep diets containing $11 \% \mathrm{CP}$ can be used to feed lambs during the preweaning period.

The objective of this study was to evaluate the effect on rearing of creep feeding suckling lambs with feeds having different protcin compositions and levels.

\section{MATERIAL AND METHODS}

Animals

The experiment was conducted on four groups of 44 lambs each ( 30 males and 14 females) from twin births (two rams or one couple). Ewes and their lambs were housed in pens with creep feeders. The ewes were not included in the study, but were fed in groups according to IZ (1993) standards with the same rations of concentrates and bulk feeds.

\section{Experimental diets}

The suckling lambs were offered creep feed from day 11 of life. The feed was composed of meadow hay and concentrates with various proportions (33-98\%) of rolled barley and contained: $16.2,13.5$ or $10.3 \%$ crude protein $(\mathrm{CP})$ in dry matter (DM), respectively for groups $\mathrm{H}, \mathrm{M}$ and $\mathrm{L}$, or a mixture with $60 \%$ rolled oats, containing $13.8 \% \mathrm{CP}$ in DM, for the control group, $\mathrm{C}$ (Table 1). The lambs had free access to the feed and water as well as salt licks containing trace elements. The concentrates and hay were given twice daily. Refusals were collected and weighed in the morning before fresh feed was given.

\section{Experimental procedure}

The lambs were weighed on days 2 and 28 of life and on two consccutive days before weaning at around 90 days of age. Feed intake, utilisation, and daily weight gain were determined from day 28 of life to weaning. Feed intake was compared 
TABLE 1

Composition and nutritive value of concentrate for suckling lambs

\begin{tabular}{|c|c|c|c|c|}
\hline \multirow{2}{*}{ Component, \% } & \multicolumn{4}{|c|}{ Group } \\
\hline & $\mathrm{C}$ & $\mathrm{H}$ & M & $\mathrm{L}$ \\
\hline Rolled barley & - & 33.3 & 63.7 & 98.0 \\
\hline Rolled oats & 59.9 & - & - & - \\
\hline Ground triticalc & 6.6 & 11.2 & 6.0 & - \\
\hline Ground wheat & 14.4 & 24.4 & 12.9 & - \\
\hline Wheat bran & 10.1 & 17.2 & 9.1 & - \\
\hline Soyabean meal & 7.0 & 11.9 & 6.3 & - \\
\hline Mineral-vitamin supplement ${ }^{\prime}$ & 2.0 & 2.0 & 2.0 & 2.0 \\
\hline \multicolumn{5}{|l|}{ In $1 \mathrm{~kg} \mathrm{DM}$ of concentrate } \\
\hline crude protein, g & 138 & 162 & 135 & 103 \\
\hline degradable, g & 103 & 119 & 100 & 78 \\
\hline undegradable, $g$ & 35 & 43 & 35 & 25 \\
\hline digested in small intestine, $\mathrm{g}$ & 31 & 35 & 28 & 21 \\
\hline PDIN, g & 112 & 129 & 105 & 77 \\
\hline PDIE, g & 107 & 123 & 112 & 99 \\
\hline UFV & 1.01 & 1.09 & 1.12 & 1.15 \\
\hline metabolisable energy, MJ & 12.8 & 12.8 & 12.9 & 13.2 \\
\hline
\end{tabular}

1 in $\%$ : calcium carbonate -45 , dicalcium phosphate -25 , commercial mineral-vitamin supplement Polfamix CJ -15 , sodium chloride -15

with the daily requirements according to IZ standards (1993). The chemical composition of the feeds was analyzed by AOAC methods (1990). Protein degradation in the rumen was determined in three cows according to Mehrez and Ørskov (1977), effective ruminal protein degradation at $\mathrm{k}_{0.06}$ was calculated according to Ørskov and McDonald (1979). Heal digestibility of protcin undegraded in the rumen (PDI) was determined using a mobile bag methods according to Hvelplund et al. (1992). The PDIN and PDIE contents were calculated according to INRA (1993) on the basis of the determined ruminal protein degradation coefficients and ileal digestibility of rumen undegraded protein. Metabolisable energy was calculated using the MAFF formula (1975), maintenance requirement was computed using the value of $418 \mathrm{~kJ} \mathrm{ME} / \mathrm{kg}^{0.75}$ (Theriez et al., 1982).

\section{Statistical analysis}

The results were subjected to one-way analysis of variance. The significance of differences between means was tested with the Tukey least significance difference test. All calculations were performed using Statgraphics ${ }^{\text {ie }}$ Plus, ver. 7.0 (1993) softwarc. 


\section{RESULTS}

Concentrate mixtures with rolled oats $(\mathrm{C})$ and rolled barley $(\mathrm{M})$ contained similar amounts of crude protein, but the PDI content of the concentrate with barlcy was about $10 \%$ lower than in the oat based concentrate (Table 1). PDI in concentrate $\mathrm{H}$, which had the highest crude protein content, was about $13 \%$ higher than in concentrate $\mathrm{C}$ with the intermediate protein content. Concentrate $\mathrm{L}$ with the lowest protein content had about $32 \%$ less PDI than concentratc $\mathrm{C}$ and $40 \%$ less than concentrate $\mathrm{H}$.

The proportion of concentrate in dry matter intake ranged from about 43 to $46 \%$ when concentrates $\mathrm{H}, \mathrm{M}$ and $\mathrm{L}$ were fed, while concentrate $\mathrm{C}$ accounted for about $52 \%$ of the ration intake (Table 2). This resulted in the differences in PDI intake being much smaller than among concentrates, and did not excecd $18 \%$ between groups $\mathrm{H}$ and $\mathrm{L}$, which were given the feeds with the highest and lowest crude protein contents.

TABLE 2

Composition and nutritive value of dry matter consumed by suckling lambs

\begin{tabular}{lcccc}
\hline \multirow{2}{*}{ Component } & \multicolumn{4}{c}{ Group } \\
\cline { 2 - 5 } & $\mathrm{C}$ & $\mathrm{H}$ & $\mathrm{M}$ & $\mathrm{L}$ \\
\hline Concentrate mixture, \% & 52.0 & 43.8 & 46.2 & 42.7 \\
Meadow hay, \% & 48.0 & 56.2 & 53.8 & 57.3 \\
& & & & \\
Crude protein, g & 130 & 139 & 128 & 114 \\
degradable, g & 89 & 93 & 86 & 76 \\
undegradable, $\mathrm{g}$ & 41 & 46 & 42 & 38 \\
digested in small intestine, g & 32 & 34 & 31 & 28 \\
& & & & \\
PDIN, g & 99 & 105 & 95 & 82 \\
PDIE, g & 97 & 103 & 98 & 92 \\
UFV & 0.83 & 0.83 & 0.85 & 0.85 \\
Metabolisable energy, MJ & 11.8 & 11.7 & 11.8 & 11.8 \\
\hline
\end{tabular}

The crude protein content in the dry matter of consumed feeds (Table 2) equaled about $130 \mathrm{~g} / \mathrm{kg}$ in groups $\mathrm{C}$ and $\mathrm{M}$, while in group $\mathrm{H}$ it was about $7 \%$ larger and about $12 \%$ lower in group L. PDI in consumed DM when the concentrates containing $14 \% \mathrm{CP}$ were fed was about $6-8 \%$ lower, while in group $\mathrm{L}$ it was $20 \%$ lower than the PDI taken up in group $\mathrm{H}$. In rations, the PDI is given as the smaller of the two values, PDIN or PDIE. Only in group L was PDIN the limiting factor, and was $10 \mathrm{~g} / \mathrm{kg}$ less than PDIE (Table 2). 
When concentrates $C, M$ and $L$ were fed, the intake of creep feed DM per $\mathrm{kg}$ metabolic body weight $\left(\mathrm{W}^{0.75}\right)$ was about $37 \mathrm{~g} / \mathrm{kg}^{0.75}$, regardless of the protein level. Only when concentrate H was fed DM intake increased to $41 \mathrm{~g} / \mathrm{kg}^{6.75}$ (Table 3).

TABLE 3 Daily nutrient and energy intake, maintenance requirement to weaning (mother milk is not taken into accotm in this calculation)

\begin{tabular}{|c|c|c|c|c|}
\hline \multirow{2}{*}{ Indices } & \multicolumn{4}{|c|}{ Group } \\
\hline & $\mathrm{C}$ & $\mathrm{H}$ & M & $\mathrm{L}$ \\
\hline $\mathrm{n}$ & 44 & 44 & 44 & 44 \\
\hline \multicolumn{5}{|l|}{ Intake/day/W $W^{075}$} \\
\hline dry matter, g & 36.7 & 41.0 & 37.6 & 37.3 \\
\hline crude protein, $\mathrm{g}$ & 4.8 & 5.7 & 4.8 & 4.2 \\
\hline metabolisable energy, MJ & 0.44 & 0.47 & 0.44 & 0.44 \\
\hline net cnergy, MJ & 0.20 & 0.22 & 0.21 & 0.20 \\
\hline \multicolumn{5}{|l|}{ Intake/day/lamb } \\
\hline dry matter. g & 272 & 282 & 261 & 260 \\
\hline crude protein, g & 35 & 39 & 33 & 30 \\
\hline metabolisable energy. MJ & 3.21 & 3.28 & 3.06 & 3.07 \\
\hline net energy. MJ & 1.46 & 1.52 & 1.45 & 1.41 \\
\hline $\begin{array}{l}\text { Daily maintenance requirem } \\
\text { metabolisable energy, MJ }\end{array}$ & 3.1 & 2.9 & 2.9 & 2.9 \\
\hline
\end{tabular}

calculated: $418 \mathrm{~kJ} \times$ mean metabolic weight $\left(\mathrm{W}^{[0.75}\right)$

Intake of concentrate DM per kg metabolic body weight was $18.0 ; 17.4$ and $15.9 \mathrm{~g} / \mathrm{kg}^{0.75}$ when concentrates $\mathrm{H}, \mathrm{M}$ and L, respectively, were given. The intake of concentrate $C$ containing oats equaled $19.1 \mathrm{~g} \mathrm{DM} / \mathrm{kg}^{0.75}$ and was about $9 \%$ greater than of concentrate $\mathrm{M}$, which had a similar crude protein content, but contained barley. The amount of PDI consumed daily $/ \mathrm{W}^{0.75}$ was equal in groups $\mathrm{C}$ and $\mathrm{M}$ $\left(1.17 \mathrm{~g} / \mathrm{kg}^{61.75}\right)$. The lambs given concentrate $\mathrm{H}$ received about $19 \%$ PDI more (1.39 $\left.\mathrm{g} / \mathrm{kg}^{0.75}\right)$, those given concentrate $\mathrm{L}$ received about $11 \%$ less $\left(1.04 \mathrm{~g} / \mathrm{kg}^{0.75}\right)$ than the lambs in groups $\mathrm{C}$ and $\mathrm{M}$.

The amount of creep feed consumed covered from 55 to $63 \%$ of DM requirements, from 40 to $54 \% \mathrm{CP}$ requirements, and from 53 to $58 \%$ of net energy requirements (Table 4) according to IZ standards (1993).

The daily weight gains of female lambs from day 2 to 28 of life differed among groups ( $\mathrm{P}<0.01$ ); those in group $\mathrm{H}$ grew slowest (Table 5) with gains about $24 \%$ smaller than those in the fastest-growing group (group $\mathrm{C}$ ). During rearing from 
TABLE 4

The nutritive value of rations in comparison with recommended allowances by IZ standards' (milk is not taken into account in this calculation)

\begin{tabular}{lcccc}
\hline \multirow{2}{*}{ Intake as per cent of requirement } & \multicolumn{4}{c}{ Group } \\
\cline { 2 - 5 } & $\mathrm{C}$ & $\mathrm{H}$ & $\mathrm{M}$ & $\mathrm{L}$ \\
\hline Dry matter & 58.5 & 63.1 & 55.3 & 56.8 \\
Crude protein & 46.4 & 53.6 & 43.2 & 40.4 \\
Net energy & 53.7 & 58.1 & 52.6 & 52.7 \\
\hline
\end{tabular}

' Nutrient Requirements of Cattle and Sheep, Traditional System (1993)

day 28 of life to weaning, the daily gains of female lambs did not differ significantly and equaled $120 \mathrm{~g}$ when concentrates $\mathrm{H}$ and $\mathrm{L}$ were fed.

Similar differences $(\mathrm{P}<0.05)$ were found in the growth rate of male lambs between days 2 and 28 of life, and those in group $\mathrm{H}$, similarly as the female lambs, grew slowest and their gains were about $17 \%$ smaller than of the young rams in the fastest growing group $(\mathrm{C})$. Between day 28 of life and weaning, the male lambs in group L grew from 9 to $22 \%$ more slowly than the others (Table 6).

The lambs utilized from 1.9 to $2.1 \mathrm{~kg}$ CP from creep feed for $1 \mathrm{~kg}$ body weight gain (ewe milk is not taken into account in this calculation). Protein utilisation was similar regardless of its level in the ration and equaled about $250 \mathrm{~g} / \mathrm{kg}$ gain, with the exception of group $\mathrm{H}$. The lambs in this group used $280 \mathrm{~g} / \mathrm{kg}$, which is $13 \%$ more than in the remaining groups (Table 7). The worst energy utilisation was found when the lambs were fed the low-protein concentrate (group L): about $12-15 \%$ worse than in group $\mathrm{C}$.

TABLE 5

Body weight and liveweight gain from birth to weaning of female suckling lambs

\begin{tabular}{|c|c|c|c|c|c|}
\hline \multirow{2}{*}{ Indices } & \multicolumn{4}{|c|}{ Group } & \multirow{2}{*}{ SEM } \\
\hline & $\mathrm{C}$ & $\mathrm{H}$ & M & $\mathrm{L}$ & \\
\hline $\mathrm{n}$ & 14 & 14 & 14 & 14 & \\
\hline \multicolumn{6}{|l|}{ Body weight, $\mathrm{kg}$} \\
\hline at 2 day of age & 4.1 & 3.9 & 3.8 & 4.1 & $0.16^{\mathrm{NS}}$ \\
\hline at 28 day of age & $9.5^{\wedge}$ & $8.0^{\mathrm{B}}$ & $8.5^{A B}$ & $9.2^{\mathrm{A}}$ & $0.30^{P(t) 61}$ \\
\hline at weaning & 17.8 & 15.5 & 17.1 & 16.9 & $0.86^{\mathrm{NS}}$ \\
\hline Days of age at weaning & $91^{\mathrm{A}}$ & $88^{\mathrm{Bi}}$ & $91^{\mathrm{A}}$ & $90^{\mathrm{ABb}}$ & $0.6^{p<0(1)}$ \\
\hline \multicolumn{6}{|l|}{ Daily liveweight gain, g } \\
\hline from 2 to 28 days of age & $208^{A}$ & $158^{13 a}$ & $178^{\mathrm{AB}}$ & $196^{\mathrm{ABh}}$ & $10.9^{P<0.01}$ \\
\hline from 28 days of age to weaning & 128 & 120 & 132 & 120 & $11.4^{\mathrm{NS}}$ \\
\hline from 2 days of age to weaning & 148 & 129 & 142 & 139 & $9.0^{\mathrm{NS}}$ \\
\hline
\end{tabular}


TABLE 6

Body weight and liveweight gain from birth to weaning of male suckling lambs

\begin{tabular}{|c|c|c|c|c|c|}
\hline \multirow{2}{*}{ Grupa } & \multicolumn{4}{|c|}{ Group } & \multirow{2}{*}{ SEM } \\
\hline & $\mathrm{C}$ & $\mathrm{H}$ & $M$ & $\mathrm{~L}$ & \\
\hline $\mathrm{n}$ & 30 & 30 & 30 & 30 & \\
\hline \multicolumn{6}{|l|}{ Body weight, $\mathrm{kg}$} \\
\hline at 2 day of age & 4.5 & 4.5 & 4.4 & 4.4 & $0.13^{\mathrm{NS}}$ \\
\hline at 28 day of age & $10.3^{\prime}$ & $9.3^{h}$ & $9.4^{\text {ih }}$ & $9.9^{\mathrm{ah}}$ & $0.34^{\text {Pd } d .05}$ \\
\hline at weaning & 19.6 & 18.5 & 17.7 & 17.3 & $0.83^{\mathrm{NS}}$ \\
\hline Days of age at weaning & $91^{A B}$ & $88^{\mathrm{C}}$ & $92^{A}$ & $90^{\mathrm{B}}$ & $0.4^{P<0.01}$ \\
\hline \multicolumn{6}{|l|}{ Daily liveweight gain, $g$} \\
\hline from 2 to 28 days of age & $224^{\mathrm{a}}$ & $185^{\mathrm{h}}$ & $190^{\mathrm{b}}$ & $210^{\mathrm{ab}}$ & $10.8^{\mathrm{P}<t .05}$ \\
\hline from 28 days of age to weaning & $142^{4}$ & $147^{a}$ & $126^{\mathrm{ab}}$ & $115^{\mathrm{b}}$ & $9.2^{P<0.155}$ \\
\hline from 2 days of age to weaning & $162^{\circ}$ & $155^{\mathrm{sh}}$ & $141^{\text {ith }}$ & $139^{h}$ & $8.1^{P<0.05}$ \\
\hline
\end{tabular}

TABLE 7

Feed utilisation per kg of gain from 28 days of age to weaning (mother milk is not taken into account in this calculation)

\begin{tabular}{lcccc}
\hline \multirow{2}{*}{ Indices } & \multicolumn{4}{c}{ Group } \\
\cline { 2 - 5 } & $\mathrm{C}$ & $\mathrm{H}$ & $\mathrm{M}$ & $\mathrm{L}$ \\
\hline $\mathrm{n}$ & 44 & 44 & 44 & 44 \\
Utilisation/kg gain: & & & & \\
dry matter, kg & 1.91 & 1.99 & 1.98 & 2.14 \\
crude protein. g & 248 & 279 & 254 & 245 \\
metabolisable energy, MJ & 22.5 & 23.2 & 23.3 & 25.3 \\
net cnergy, MJ & 10.2 & 10.7 & 11.0 & 11.7 \\
\hline
\end{tabular}

\section{DISCUSSION}

INRA (1993) standards do not give requirements for suckling lambs. IZ standards (1993) give from $170 \mathrm{~g}$ in the early stage to $154 \mathrm{~g} \mathrm{CP} / \mathrm{kg} \mathrm{DM}$ in the last ten days before weaning (days 91-100 of life) for suckling lambs. The crude protein content in the DM of rations for the period of creep feeding lambs from days 28 to 100 computed on this basis is $160 \mathrm{~g} / \mathrm{kg} \mathrm{DM}$, and the energy value of the ration is $5.84 \mathrm{MJ}$ EN/kg DM.

The results of this experiment confirmed carlier conclusions (Pająk et al., 1994) that male lambs are more prone to react to a decreased protein content in creep feed by reducing body weight gain than are female lambs. From day 28 of 
life to weaning, female lambs grew similarly, and their gains did not depend on the protein content of the concentrate, while the male lambs given the creep feed with the lowest protein content grew more slowly $(\mathrm{P}<0.05)$ than those in the other groups, which confirms the widespread opinion about the smaller protein requirement of female lambs than of male lambs.

After 28 days of life, the growth rate of male lambs given creep feed containing barley was about 14 and $22 \%$ slower in groups $M$ and $L$ than in the young rams in group $\mathrm{H}$ (Table 6 ). This was probably caused by the approximately 8 and $20 \%$ lower PDI intake in the daily rations in these groups in comparison with group H (Table 2).

The reduction of feed consumption when the protein content of the ration is lowered is a known occurrence (Ensminger et al., 1990). Suckling Polish Lowland lambs fed meadow hay and concentrates containing from 123 to $167 \mathrm{~g}$ crude protein in DM grew similarly. Feeding concentrates containing less than $15 \%$ crude protein in DM lowered feed intake, resulting in slightly lower gains. The differences in the gains were not statistically significant because of the high intragroup variability resulting from the lack of full genetic consolidation of this breed, as well as from variability within sibling pairs (Pająk et al., 1994).

By lowering the crude protein level in DM of barley concentrates by 17 and $36 \%$ in comparison with group $\mathrm{H}$ (groups $\mathrm{M}$ and $\mathrm{L}$ ), the amount of PDI in the DM of consumed feed decreased by about 9 and $18 \%$ (Table 2), but the reaction of suckling lambs was similar, and was manifested as reduced consumption of $\mathrm{DM} / \mathrm{kg}^{0.75}$ by 8.3 and $9.0 \%$ in groups $\mathrm{M}$ and $\mathrm{L}$, respectively (Table 3 ). Purroy et al. (1993) also report that male lambs fed rations containing $12 \%$ crude protein consumed significantly less feed per $\mathrm{kg}^{0.75}$ than at 15 or $18 \%$ protcin contents. At a similar reduction of 9 and $22 \%$, the amount of PDI in DM of the consumed ration (Pajak et al., 1994) and intake of $\mathrm{DM} / \mathrm{kg}^{0.75}$ declined by 14.8 and $15.5 \%$ in comparison with the group fed the concentrate with the same (167 g) crude protein content as in the presently described experiment $(162 \mathrm{~g} / \mathrm{kg} \mathrm{DM})$. No explanation for this observation has been found. Sawal et al. (1996) reported that in Gaddi $x$ Merino lambs, fed in suckling period isoenergetic diets containing 11 to $21 \% \mathrm{CP}$, DM intake of creep feed was not affected by the level of protein.

Analysis of daily consumption of metabolisable energy in solid feeds and the maintenance requirements of lambs (Table 3 ) shows that in groups $M$ and $L$, the amount of energy available for growth was similar: 0.16 and $0.17 \mathrm{MJ} \mathrm{EM} / \mathrm{lamb}$ daily. In an earlier experiment (Pająk et al., 1994) lambs in similar groups consumed 0.42 i $0.49 \mathrm{MJ}$ EM/lamb daily. In both experiments the decline in consumption of metabolisable energy available for growth in groups fed the concentrates with the lowest protein content in comparison with those fed concentrate $\mathrm{H}$ containing 162 or $167 \mathrm{~g} \mathrm{CP} / \mathrm{kg}$ DM was identical and equaled $55 \%$. When feeds containing 135 or $147 \mathrm{~g} \mathrm{CP} / \mathrm{kg}$ DM were given, intake was also similar in 
the two expcriments and equaled 58 or $61 \%$, respectively. Despite such large differences in the consumption of metabolisable energy available for growth, this had no effect on the gains of female lambs, and the lowering of the growth rate of male lambs did not exceed $23 \%$ in either experiment.

Villette and Theriez (1981) reported that during suckling, the intake of feed per kg metabolic body weight was independent of the birth weight of male lambs, but their daily gain was positively correlated with it. In our experiment, in which groups were fed creep feed, we did not find a statistically proven influence of birth weight of lambs on daily gains after 28 days of life.

Both during fattening (Pająk et al., 1993) and rearing (Pająk et al., 1994), Polish Lowland lambs consume less DM feed than the IZ standards (1993) give. In the present experiment, DM intake by lambs was, in comparison with these standards, smaller by $37 \%$ (in the group fed the concentrate with the highest crude protein content) to $45 \%$ in the groups fed concentrates with reduced protein contents (Table 4). In an earlier experiment (Pająk et al., 1994) lambs in similar groups consumed from 10 and $22-24 \%$ less DM than given in the IZ standards (1993).

The reduction in crude protein intake in relation to the standards (Table 4) results from lower DM intake and the methodology used in the experiment (lowering the protein content of the offered feeds). Lower feed consumption in the present experiment together with the lower birth weight of the lambs explains their slower growth rate.

According to Ensminger et al. (1990) oat grain is a better feed for sheep than barley. On comparing the results of rearing the group $\mathrm{C}$ lambs-fed the concentrate containing about $60 \%$ rolled oats-with those of group $\mathrm{M}$ lambs that were fed a concentrate having the same protein content (CP, PDI) but containing barley, it was found that the intake of the barley-containing concentrate was about $15 \%$ lower. The daily intake of ileal digestible protein was about $7 \%$ lower in group $\mathrm{M}$ than in $\mathrm{C}$, which may account for the approximately $11 \%$ smaller daily gains of male lambs after 28 days of life (Table 6 ).

These results do not corroborate those of Ørskov et al. (1974) who showed that during fattening from a body weight of about 15 to $35 \mathrm{~kg}$, lambs that had been weaned early had $29 \%$ greater gains and $11 \%$ better feed utilisation when fed with barlcy rather than oats. This may have been caused by the poorer development of the rumen and its function, which is indicated by the $55 \%$ higher gut content (\% of liveweight) and $11 \%$ worse digestibility of organic matter of rations containing oats than barley.

The magnitude of daily gains could also have been modified by the dam's milk yield (Snowder i Glimp, 1991), which was not measured in this experiment. According to the cited authors, the correlation between milk yield and the growth rate of lambs is significant: up to day 56 it does not exceed 0.75 for single and 0.6 for 
twins. A decline in maternal milk yicld causes an increase in crecp feed consumption (Ørskov, 1983). It seems that in the final stage of lactation, maternal milk yield is no longer a significant factor, since during this time solid feed intake by lambs increases. This is supported by the results of Frey et al. (1991), who found that Finn-Targhee dams given additional concentrates during grazing produced more $(\mathrm{P}<0.05)$ milk in the final stages of lactation $(724$ vs $586 \mathrm{ml} /$ day $)$ than those not given supplementary feed, but this had no effect on the body weight gains of the nursing twins. Milk intake was positively $(\mathrm{P}<0.01)$ related to growth, however, feed DM intake was not related to milk intake (Sawal et al., 1996).

In our expcriment we did not determine the weight of the mothers at lambing, and, according to Barghout and Abdel-Aziz (1989), this has an influence $(\mathrm{P}<0.01)$ on daily gains and the weight of lambs at weaning at 10 weeks. On the basis of the growth of lambs of both sexes from day 2 to 28 of life, it can be assumed that the mothers of the lambs in group $\mathrm{C}$ produced more milk than the others (Tables 5 and 6). During this period, the gains of lambs in group $\mathrm{H}$ were about 24 and $17 \%$ smaller than in group $\mathrm{C}$, in female and male lambs, respectively. In group M, lambs regardless of sex grew 14-15\% more slowly, and in group L, about 6\% more slowly than those in group C. This could also have affected the growth rate of lambs in later periods, since maternal milk yield in the first month of lactation affects lamb performance in the subsequent weeks of lactation (Bocquier et al., 1987).

The gains of suckling lambs (Tables 5 and 6) were relatively small, smaller than in an carlier experiment (Pająk et al., 1994), as well as smaller than of lambs of other breeds (Kosanovič et al., 1977; Potkański et al., 1991a,b; Urbaniak and Potkański, $1991 \mathrm{a}, \mathrm{b})$. This may be related to the dependence described by Villette and Theriez (1981) between the birth weight of lambs and their gains during suckling. Lambs that weigh more at birth gain faster, moreover, they gain less fat (INRA, 1993). In our experiment, female lambs in particular were lighter 2 days after birth than in the previous experiment $(3.9 ; 3.8$ and 4.1 vs $4.0 ; 4.3$ and 4.5 in groups $\mathrm{H}, \mathrm{M}$ and L, respectively; Pająk et al., 1994). The birth weight of lambs, maternal milk yield, and related growth rate of lambs are significantly affected by the year of the experiment (Niżnikowski et al., 1991).

Feed utilisation (excluding milk) did not differ among groups (Table 7) and was slightly better than in the earlier experiment (Pająk et al., 1994).

\section{CONCLUSIONS}

During suckling period, a reduction in the protein content of the feed mixture used in creep feeding lambs from 16 to about 14\% in DM does not adversely affect gains, but a feed containing about $10 \% \mathrm{CP}$ in $\mathrm{DM}$ is unsuitable for this group of animals. 
Suckling Polish Lowland lambs consume less DM than given in the IZ standards (1993) foresee therefore, it is necessary to adjust requirements for DM and for the possibility of implementing economical protein nutrition.

\section{REFERENCES}

AOAC, 1990. Association of Official Analytical Chemists, Official Methods of Analysis. $15^{\text {th }}$ Edition. Arlington, VA

Barghout A.A., Abdel-Aziz A.S., 1989. A comparative study of body weight and growth rate of Turkish and Barki lambs during the suckling period. Egyptian J. Anim. Prod. 26, 47-54

Bocquier F., Theriez M., Brelurut A., 1987. Recommendations alimentaires pour les brebis en lactation. Bull. Tech. CRZV Theix, INRA 70, 199-211

Ensminger M.E., Oldfield J.E., Heinemann W.W., 1990. Fecds and Nutrition. $2^{\text {nd }}$ Edition. Ensminger Publishing Co., Clovis. California, pp.1544

Frey A., Thomas V.M., Ansotegui R., Burfening P.J., Kott R.W., 1991. Influence of escape protein supplementation to grazing ewes suckling twins on milk production and lamb performance. Small Ruminant Res. 4, 1-10

Hvelplund T., Weisbjerg M.R.. Andersen L.S. 1992., Estimation of the true digestibility of rumen undegraded dietary protcin in the small intestine of ruminants by the mobile bag technique. Acta Agr. Scand., Sect. A., Anim. Sci. 42, 34-39

INRA: Ruminant Nutrition. Recommended Allowances and Feed Tables, 1993. R, Jarrige (Editor). Polish Edition, The Kielanowski Institute of Animal Physiology and Nutrition, Jabłonna, pp. 406

IZ: Nutrient Requirements of Cattle and Sheep. Traditional System (in Polish). 1993. R. Ryś (Editor). Rescarch Institute for Animal Production, Kraków, pp. 103

Kosanovič M., Ivos R., Krajinovič M., 1977. Intensive production of lamb meat in the suckling period. Zb. Radova, Institut za Stocarstvo, Novi Sad 9/10, 109-115

MAFF, 1975. Energy Allowances and Feeding System for Ruminants. Techn. Bull.33. London

Mehrez A.Z., Ørskov E.R., 1977. A study of the artificial fibre bag technique for determining the digestibility of feeds in the rumen. J. Agr. Sci. 88, 645-650

Niżnikowski R., Rant W. Tyszka Z.J., Janikowski T.J., 1991. Effect of various factors on some milk performance traits in East Friesian and Corriedale type ewes during a 12-week lactation (in Polish). Rocz. Nauk. Zoot. 18, 129-139

Ørskov E.R.. 1983. Nutrition of lambs from birth to slaughter. In: W. Haresign (Editor). Sheep Production. Butterworths, London, pp. 155-165

Ørskov E.R., Fraser C., McHattie I., 1974. Cereal processing and food utilization by sheep. 2. A note on the effect of feeding unprocessed barley, maize, oats and wheat on food utilization by earlyweaned lambs. Anim. Prod, 18, 85-88

Ørskov E.R., McDonald I., 1979. The estimation of protein degradability in the rumen from incubation measurements weighted according to rate of pasage. J. Agr. Sci. 92, 499-503

Pająk J.J.. Słowak M., Dakowski P., 1993. Fattening performance of Polish Lowland lambs related to protein level in the diet. J. Anim. Feed Sci. 1, 193-203

Pająk J.J., Wójciak M., Janocha A.. 1999. Yellow lupin seeds in feeding of suckling Polish Lowland lambs. Requirements of high productive farm animals (in Polish). Agricultural University of Crakow (Editor), pp.185-188

Pająk J.J., Zebrowska T., Słowak M., 1994. The effect of the protein level in diets of Polish Lowland lambs on growth and fattening. J. Anim. Feed Sci. 3, 263-278 
Potkański A, Urbaniak M., Kujawa A., 1991a. Utilization of post-extraction rapeseed meal to replace post-extraction soyabean meal in concentrates used in feeding suckling lambs (in Polish). Rocz. AR Poznań 228. Zoot. 41, 45-53

Potkański A., Urbaniak M., Kujawa A., $199 \mathrm{lb}$. Utilization of "OO” rape seeds in CJ concentrates used in feeding suckling lambs (in Polish). Rocz. AR Poznañ 228, Zoot. 41, 85-96

Purroy A., Echaide H., Munoz F. Arana A., Mendizabal J.A., 1993. The effect of protein level and source of legume seeds on the growth and fattening of lambs. Livest. Prod. Sci. 34, 93-100

Sawal R.K., Bhatia D.R., Bhasin V., Solanki V.K., 1996. Effect of dietary levels of protein on preweaning growth of lambs. Indian J. Anim. Nutr. 13, 31-34

Snowder G.D., Glimp H.A., 1991. Influence of breed, number of suckling lambs, and stage of lactation on ewe milk production and lamb growth under range conditions. J. Anim. Sci. 69, 923-930

Statgraphics Plus ver. 7., 1993. Statistical Graphics System by Graphics Corporation

Theriez M., Villette Y., Castrillo C., 1982. Influence of metabolizable energy content of the diet and of feeding level on lamb performance. Il. Utilization of metabolizable energy for growth and fattening. Livest. Prod. Sci. 9, 487-500

Urbaniak M.. Potkański A.. 1991a. Effect of rapeseed oilmeal content in CJ concentrate mixture on weight gains of lambs and calves and on thyroxine and triiodothyronine levels in blood serum (in Polish). Rocz. AR Poznań 228, Zoot. 41, 37-44

Urbaniak M., Potkański A., 1991b. Effect of soyabean and rapeseed oilmeals and ground pea seeds on sheep fertility (in Polish). Rocz. AR Poznań 228, Zoot. 41, 55-61

Villette Y., Theriez M., 1981. Effect of birthweight on lamb performance. 1. Level of feed intake and growth. Ann. Zootech, 30, 151-168

\section{STRESZCZENIT:}

Odchów jagniąt ssących polskiej owcy nizinnej dokarmianych mieszankamj o różnej zawartości bialka

Cztery grupy, po 44 jagniąt ssących (w tym 14 jarck i 30 tryczków), dokarmiano sianem łąkowym i mieszanką treściwą z jęczmieniem zawicrającą: 162, 135 lub 103 g białka ogólnego w suchcj masie - grupy H, M i L, odpowiednio, bądź mieszanką z owsem zawierającą $13.8 \%$ białka ogólnego w suchej masie - grupa C. Ograniczenic pozionu białka w mieszance do ok. $14 \% \mathrm{~W}$ suchej masie nie spowodowało pogorszenja przyrostów jagniąt, natomiast przy skarmianiu mieszanki o ok. 10\% białka stwierdzono istotne pogorszenie tempa wzrostu tryczków.

Od 28 dnia życia do odsadzenia (w 89-93 dniu życia) przyrosty jarek nie różniły się istotnie między grupami i wynosiły $120-132 \mathrm{~g}$ dziennic, tryczki przyrastały średnio po $142^{\mathrm{a}}, 147^{\mathrm{a}}, 126^{\mathrm{ab}}$ i $115^{\text {h }} \mathrm{g}(\mathrm{P}<0.05) \mathrm{w}$ grupach $\mathrm{C}, \mathrm{H}, \mathrm{M}$ i L, odpowiednio.

Jagnięta ssące polskiej owcy nizinnej zjadają mnicj s.m. niż przewidują normy IZ, zachodzi zatem potrzeba wprowadzenia w nich korekty zapotrzebowania na s.m. oraz białko. 